\title{
BANKRUPTCY PREDICTION MODELS IN THE SERBIAN AGRICULTURAL SECTOR ${ }^{1}$
}

\author{
Danica Rajin', Danijela Milenković3 ${ }^{3}$, Tijana Radojevićc
}

\begin{abstract}
Summary
The aim of this paper is to present different models for predicting the possibility of opening bankruptcy proceedings in companies in Serbia, as well as to research which models are most suitable for companies in the agricultural sector. In this paper, we have used and displayed three models: the Altman's Z-score model, Kralicek's DF model and Quick test. Many authors have dealt with this issue, but most of them have developed models for developed markets, which are different from market of Serbia. Striving towards improving the analysis and prediction of bankruptcy has led to comparison of the reference value, in order to obtain concrete models for the evaluation of difficulty in the functioning of the company. In this connection, on a sample of five companies operating on the territory of the Republic of Serbia, we have applied three models that used standard financial indicators to show the financial condition and stability of the company. Results suggest that Kralicek's DF model indicates better financial state of the company than Altman's Z-score model, considering the characteristics of the market in which the model is formed.
\end{abstract}

Key words: Altman's Z-score, DF model, Quick test, models of predicting bankruptcy proceedings

JEL: $Q 14, M 21, G 33$

1 This Research Paper was the part of the project "Advancing Serbia's Competitiveness in the Process of EU Accession", no. 47028, financed by Serbian Ministry of Science and Education.

2 Danica Rajin, Ph.D., Teaching Assistant, Singidunum University, Faculty of Economics, Finance and Administration FEFA, Boulevard Zoran Đinđić no. 44, 11000 Belgrade, Serbia, Phone: +381 113122 440, E-mail: drajin@fefa.edu.rs

3 Danijela Milenković, M.Sc., Teaching Assistant, Singidunum University, Faculty of Economics, Finance and Administration FEFA, Boulevard Zoran Đinđić no. 44, 11000 Belgrade, Serbia, Phone: +381 113122 440, E-mail: dmilenkovic@,fefa.edu.rs

4 Tijana Radojević, Ph.D., Associate Professor, Singidunum University, Faculty of Business in Belgrade, Danijelova Street no. 32, Belgrade, Serbia, Phone: +381 113093 220, E-mail: tradojevic@singidunum.ac.rs

EP 2016 (63) 1 (89-105) 


\section{Introduction}

Agriculture is one of the most significant economic sectors in Serbia. Having in mind convenient geographic position of the country, its climate, as well as the high quality of the soil, this sector contributes to social and economic development of the country (Tankosić, Stojsavljević, 2012). Significant resources are required in order to exploit all the potential, conduct specialization in production, increase production efficiency and effectiveness using modern technologies (Maletić et al., 2011). During the last decade, significant funds were invested in the agricultural industry in Serbia. The total amount of investment in the agricultural sector exceeded $\$ 1$ billion since 2000. Foreign companies have entered the Serbian market, mainly through acquisition and greenfield investments, particularly in the beverage sector, sugar, milk, meat industry (Ministry of Agriculture, Forestry and Water Management of the Republic of Serbia, 2014).

Over 90 percent of the companies that do business in this sector have now switched to market economy. By this transition, the employers saw a great deal of significance in inspecting the various aspects of operating so as not to have companies become insolvent. The specifics that define the way in which business is carried out in agricultural companies is their seasonal character, slow turnover and high production costs (Jakšić et al., 2011). The mere beginning of the development of market economy is defined by the comparison of relevant indicators of value. However, a simple comparison of values did not produce accurate results, and neither was effective. With further development of the economy, and economic and mathematical models, different models for predicting bankruptcy of enterprises have been developed. According to Zenzerovic and Perusko (2006) the most commonly used models in practice for prediction of bankruptcy are: Beawer, Altman, Deakin, Ohlson, Edmistera, Zavregena and Kralíček.

The aim of this study is to explore which models of predicting bankruptcy proceedings are most suitable for companies in the agricultural sector.

\section{Literature review}

The most used method in predicting the bankruptcy of the company was created as a result of Altman and other authors in the period from 1968 to 2002. The first paper on this topic (Altman, 1968) conducted research on a sample of companies of the US markets. He made a comparison of companies that have positive financial, as well as those that have been initiated bankruptcy proceedings. Observing twenty-two indicators that he considered to be of potential help, he set aside five standard ones that he included in his model with appropriate importance. Later, he has done a modification of the initial model, and formed models for companies whose shares are not traded on stock exchanges.

Beaver (1967) carried out research in the field of ratio analysis and the relations of bankruptcy classification. His univariate analysis based on a large number of bankruptcy indicators represents the starting point for multivariate attempts, both Beaver and for 
other studies that followed. Beaver found that a number of indicators could discriminate between matched samples of failed and no failed firms for as long as five years prior to failure. Deakin (1972) in the latter study followed the same 14 variables that Beaver analyzed, but he applied them within a series of multivariate discriminant models.

Another famous prediction model was developed by Ohlson (1980). He published the paper where he indicated the shortcomings of MDA (Multivariate Discriminant Analysis) model and suggested logit analysis that avoids all the shortcomings of the previous model in the mentioned paper. The work was based on finding answers to the question: If given company belongs to a specific population, what is the probability of its bankruptcy? Therefore, the analysis without pre-defined probability of bankruptcy and without probability of distribution indicators. The analysis resulted with the creation of three models of predicting bankruptcy within the first year, predicting within the second year, if not in the first bankruptcy proceedings and bankruptcy prediction within a period of two years. It turned out that the first model has the highest probability of predictions, with the remark that the strength predictions of any model depends on the amount of information that we have.

After twenty-five years of developing Taffler models, Agarwal and Taffler (2007) provided a detailed study which involved a series of tests to prove the accuracy of the model for predicting bankruptcy. Detailed review of the Taffler model leads to the conclusion that the model accurately predicts failure in business. Also, the authors draw the attention to the fact that this model is useful for predicting the business of banks, rather than alternative companies. However, it is of great importance to interpret financial indicators correctly. Therefore, that is one thing that they agree with other authors.

Jakovčević and Andrašević (2011) published a paper about the indicators of problems in the functioning of industrial companies. In this paper, the authors provide a detailed overview of Altman's and Kralicek's models. They were assessed the overall state of observed companies testing on specific models listed industrial companies, whose shares are not traded on the stock exchange. A year later the same authors apply these models to predict the financial stability of agricultural companies.

Alihodžić (2013) in his paper also states that the models are extracted in the research, but its focus is directed towards Kralicek's DF test indicators, as well as the possibility of applying to the individual companies within the index BELEXline. In conclusion of the paper he stated that there are certain obstacles for application of the model to companies in Serbia, of which the most significant are performed unavailability of data and low training of researchers in the field of econometrics. Regarding to this Alihodžić (2013) notes that companies and financial institutions that the US financial markets were forced to bankruptcy, in Serbia continue to operate, in appreciation to the impact of inefficient financial and legal systems". Also, it is proposed as the best solution to combine financial indicators and models to predict the future of the company. 
Muminović et al. (2011) tested the original Z-Score model and revised y-Score model for private companies in the Republic of Serbia. This study tested the ability to predict bankruptcy using the Z-Score model on a sample of Serbia. They concluded that the original Z-Score model cannot be successfully applied to domestic companies. Pavlović et al. (2011) find that Tafller's model cannot be applied to the companies in Serbia, which entitle the Taffler's assertion according to the specificity of the Z-Score model, therefore it can be applied only to companies which it was developed. Muminović et al. (2012) concluded that investing results in changing the financial position and profitability of a company, and the direction and intensity of any upcoming changes cannot be predicted by any model; especially, they could not be predicted by a model based on the discriminant analysis. Stanišić et al. (2013) deal with prediction of the probability of bankruptcy for the companies in Serbia. In a sample of 130 commercial companies they use the method of logistic regression, decision tree methods and artificial neural networks. Comparing the results with Altman's model, they concluded that the only model of neural network shows better results, which indicate that a vital form of bankruptcy prediction models for emerging markets with the characteristics of the recession, what is the market in Serbia.

In the case of the Czech Republic (Machek, 2014) examine in what percentage of Karlicek's Quick test, Taffler's model, IN99 and IN05 indexes of credibility, as well as Altman's model correctly predicted the bankruptcy of the company. It has been shown that the indexes of credibility and Altman's model provided the best results. This confirms the fact of the universality of application of the appropriate Altman's test. A good result of the credibility index was expected, since this model has been developed especially for the Czech market.

Smaranda (2014) developed a model based on logistic regression for which finds that most appropriate data composed of SMEs accounting ratios from a central-east European emerging economy. It is recommended that financial institutions wellassessment parameters from classical score and to review of financial ratios, especially in time of financial crises.

Recent years a great deal of attention was paid to the Kralicek's Quick test (Didenko et al., 2012). The Quick test is employed on Latvia's example in a study that evaluates the accuracy of bankruptcy prediction. The authors of this work deducted that the indicator election is rather important and that the prediction is 27 percent better in two years' time and 18 percent in three years' time if the calculations use the net money flow as opposed to the net money flow reduced by EBITDA.

Polo and Caca (2014) in the case of Albania test Quick test and provide a graphical representation of evaluation by 2010-2012. The study has shown that the greater the average value of the Quick test is, the lesser the total ability of payment. Due to the different factors involved in this review, the authors drew attention to the importance of the weightiness of each indicator for predicting crisis of the entire economic community. 


\section{Methodology}

Prediction of the problems in business operations initially relied on the observation values of individual financial indicators. The disadvantage of this type of analysis was the fact that was able to get individual indicators for independent problems. Striving to improvement of analysis has led to the comparison of the reference value, therefore there was a specific model for the evaluation of difficulty in the functioning of the company. With the increasing availability of information and data, as well as the rapid development of information technology has facilitated comparison of data, as well as determination of cause-effect relationships of one to the other indicators. A large number of papers have been published as a result of investigations of the issue by various authors. Through time these studies were constructing a large number of mathematical models which were aimed at predicting bankruptcy of companies.

This paper analyzes the application of the two most commonly used models: Altman's model, constructed on a sample of US companies, and Kralicek's model, constructed on a sample of European companies.

Edward I. Altman's model, designed in 1968, in the literature is known as the Altman's Z-score. The study included sixty six companies in the same industrial area, divided into two groups (Altman, 1968). The main aim of the research was to find a model that describes the difficulties in the business, and the prediction of corporate bankruptcy. Altman compared the group of companies that was already in bankruptcy, with a group at the time research continues to operate. The result of the research proved to be very significant. Method of multivariate discriminant analysis was tested the influence of parameters on the probability of occurrence bankruptcy. Of the twenty-two financial indicators, which is involved in the research, it turned out that only five describe properly company's operations. The final discriminating function is as follows:

$$
\mathrm{Z}=1.2 \cdot \mathrm{X}_{1}+1.4 \cdot \mathrm{X}_{2}+3.3 \cdot \mathrm{X}_{3}+0.6 \cdot \mathrm{X}_{4}+1.0 \cdot \mathrm{X}_{5}
$$

whereby the major indicators are defined as follows:

$\mathrm{Z}=$ the overall index, which also referred $\mathrm{Z}$-score

$\mathrm{X}_{1}=$ working capital/total assets

$\mathrm{X}_{2}=$ retained earnings/total assets

$\mathrm{X}_{3}=$ earnings before interest and taxes/total assets

$\mathrm{X}_{4}=$ market value equity/book value of total debt

$\mathrm{X}_{5}=$ sales/total assets.

The value of Z-score, calculated according to the formula above, was an indication of whether the company has difficulty in functioning or not. According to Altman, if the value of $\mathrm{Z}$-score greater than 2.67 indicates that the company is financially stable and it is located in the white zone or "non-bankrupt sector". The area between 1.81 and 2.67 , will be defined as the "zone of ignorance" or "gray zone", because the company 
is financially vulnerable but there is potential for improvement of business. Hence, it is desirable to establish a guideline for classifying companies in the "gray area". While those firms having a Z-score below 1.81 are all bankrupt, which indicate "black areas".

This model has been established on a sample of companies whose shares were traded on stock exchange. There are a large number of companies whose shares are not traded on the stock exchange, therefore Altman has performed a modification of this model, in order to be adapted for other companies. Thus, the factor $\mathrm{X}_{4}$ instead of the market value of equity for these companies uses the book value of capital and the value of the $\mathrm{Z}$-score is calculated by the following formula:

$$
Z^{\prime}=0.717 \cdot X_{1}+0.847 \cdot X_{2}+3.107 \cdot X_{3}+0.420 \cdot X_{4}+0.998 \cdot X_{5}
$$

Amended the reference values are vulnerability and the company considered financially stable if $Z$ ' $>2.9$. The potential for improved business operations have company with $1.23<Z$ ' $<2.9$, while the risk of bankruptcy exists for companies with values of Z' below than 1.23. Furthermore, Altman performed another modification for non-production companies. The main difference is the exclusion of indicators $\mathrm{X}_{5}$, since depending on the field of business, values of this factor can vary considerably. The new model forms:

$$
Z "=6.56 \cdot X_{1}+3.26 \cdot X_{2}+6.72 \cdot X_{3}+1.05 \cdot X_{4}
$$

where the lower and upper limits of the financial stability as follows 1.10 and 2.60.

Another method that we used for determining the probability of bankruptcy will be, as we have already mentioned, Kralicek's model. Following the example of Altman's idea, Kralicek was taken as a sample European companies and create a new discriminant function (Alihodžić, 2013). Kralicek's DF indicator is calculated using six indicators and may use positive and negative values. Value of Kralicek's DF indicator is calculated according to the formula:

$$
\mathrm{DF}=1.5 \cdot \mathrm{X}_{1}+0.08 \cdot \mathrm{X}_{2}+10 \cdot \mathrm{X}_{3}+5 \cdot \mathrm{X}_{4}+0.3 \cdot \mathrm{X}_{5}+0.1 \cdot \mathrm{X}_{6}
$$

Indicators that participate in this model are the following:

$\mathrm{DF}=$ the value of the discriminant function

$\mathrm{X}_{1}=$ net cash flow/total liabilities

$\mathrm{X}_{2}=$ total assets/total liabilities

$\mathrm{X}_{3}=$ profit/total assets

$\mathrm{X}_{4}=$ profit/operating income

$\mathrm{X}_{5}=$ inventories/operating income

$\mathrm{X}_{6}=$ operating income/total assets 
Kralicek's DF indicator may have positive and negative values, where the negative point to the existence of insolvency, and positive on the solvency of monitored business entity. Insolvency starts when the DF indicator's value is in the 0.0-0.3 interval after which the zone of moderate insolvency commences for the DF indicator's values lesser than 0.0 and greater than -0.1 at which point the zone of extreme insolvency begins. Financial stability for the indicator values higher than 0.3-1.0 is rather bad and for the values from 1.0-1.5 financial stability is medium. With the business subjects that have a DF value between 1.52.2 the stability is good while up to 3 the stability is very good. All companies that possess a DF indicator above 3 are considered to be businesses with extraordinary financial stability (Alihodžić, 2013).

Depending on the value of the DF indicator, determines whether the company is solvent or not. Critical values point to the financial stability of the company are given by the following table.

Table 1. The values of Kralicek's DF indicator

\begin{tabular}{|c|c|}
\hline The values of DF indicator & Financial stability \\
\hline$>3.0$ & Excellent \\
\hline$>2.2$ & Very good \\
\hline$>1.5$ & Good \\
\hline$>1.0$ & Average \\
\hline$>0.3$ & Bad \\
\hline 0.3 & Beginning of insolvency \\
\hline$\leq 0.0$ & Moderate insolvency \\
\hline$\leq-1.0$ & The striking insolvency \\
\hline
\end{tabular}

Source: Alihodžić (2013)

Kralicek has formed another model whose purpose is based on minimal data in order to return the maximum information (Alihodžić, 2013). This test is known as the Quick test by Kralicek. The purpose of the model is evaluating the financial performance of companies, as well as the profitability of funds. The test involved four indicators that measure the risk of funding, liquidity, profitability and success. Each indicator is assigned a rating from 1 to 5 depending on the value, where 1 is the best rating. Indicators participating in the test are calculated as follows (Alihodžić, 2013):

$\mathrm{X}_{1}=$ equity/total liabilities. Shows the share of capital in total liabilities. The recommended value of the indicator is $10 \%$ or higher.

$\mathrm{X}_{2}=($ total liabilities $-\mathrm{cash}) /($ net profit + amortization $)$. This indicator shows the time of debt repayment, i.e shows what the ratio between liabilities minus cash and profit is after tax, increased for amortization. If the value of this indicator is above 30 (years), it is deemed that the company has certain difficulties with solvency. It is advised that the value of this indicator should be 12 years or less.

$\mathrm{X}_{3}=\mathrm{EBIT} /$ total assets. This indicator shows profitability of total assets in respect to 
operative gains. If the value of this indicator is negative, company has certain difficulties with solvency. It is advised that the value of this indicator should be $8 \%$ or higher.

$\mathrm{X}_{4}=$ (net profit + amortization)/business earnings. If the value of this indicator is negative, company has certain difficulties with solvency. It is advised that value of this indicator should be $5 \%$ or higher.

The following table presents a method for assigning evaluation indicators.

Table 2. Assigning points of Kralicek's Quick test

\begin{tabular}{|l|l|l|l|l|l|}
\hline Indicator & $\begin{array}{l}\text { Excellent } \\
\mathbf{1}\end{array}$ & $\begin{array}{l}\text { Very good } \\
\mathbf{2}\end{array}$ & $\begin{array}{l}\text { Good } \\
\mathbf{3}\end{array}$ & $\begin{array}{l}\text { Bad } \\
\mathbf{4}\end{array}$ & $\begin{array}{l}\text { Risk of } \\
\text { Insolvency } \\
\mathbf{5}\end{array}$ \\
\hline $\mathrm{X}_{1}$ & $>30 \%$ & $>20 \%$ & $>10 \%$ & $>0 \%$ & Negative \\
\hline $\mathrm{X}_{2}$ & $<3$ years & $<5$ years & $<12$ years & $<30$ years & $>30$ years \\
\hline$\left(\mathrm{X}_{1}+\mathrm{X}_{2}\right) / 2$ & Financial stability & $>0 \%$ & Negative \\
\hline $\mathrm{X}_{3}$ & $>10 \%$ & $>8 \%$ & $>5 \%$ & Negative \\
\hline $\mathrm{X}_{4}$ & $>15 \%$ & $>12 \%$ & $>8 \%$ & $>0 \%$ & \\
\hline$\left(\mathrm{X}_{3}+\mathrm{X}_{4}\right) / 2$ & \multicolumn{5}{l}{} \\
\hline$\left(\mathrm{X}_{1}+\mathrm{X}_{2}+\mathrm{X}_{3}+\mathrm{X}_{4}\right) / 4$ & \multicolumn{6}{l}{} \\
\hline
\end{tabular}

Source: Alihodžić (2013)

As we have presented in the table, the arithmetic average of the first two indicators represent an evaluation of the financial stability of the company, while the average value of the other two, are actually an indicator of the overall success and profitability.

\section{Results}

The aim of this paper is to present which indicators point to problems in the company functioning. The methods that are described in the previous chapter are applied to companies which are operating in the Republic of Serbia. The research included five companies from the agricultural sector. The observed time period is from 2010 to 2013. The data that were used in the research were taken from the financial statements of companies in the agricultural sector which are available on the website of the Serbian Business Registers Agency. All results that are listed in the research are estimates of the authors.

As well as we described in the methodology, the research has begun with calculating Altman's Z-score. Given the fact that the research included only companies from agricultural sector, and that their shares are not traded on the stock exchange, for each of the companies accounted we value indicator $Z$ '. The results that we obtained are given in the following table. 
Table 3. Estimate of Altman's Z-score for the companies in the sample

\begin{tabular}{|l|l|l|l|l|}
\hline \multirow{2}{*}{ Company } & \multicolumn{4}{l|}{ The values of Z'- indicator } \\
\cline { 2 - 5 } & $\mathbf{2 0 1 0}$ & $\mathbf{2 0 1 1}$ & $\mathbf{2 0 1 2}$ & $\mathbf{2 0 1 3}$ \\
\hline A & 1.52 & 1.99 & 1.72 & 1.75 \\
\hline B & 0.32 & 0.37 & 0.26 & -0.01 \\
\hline C & -0.05 & 0.39 & 0.80 & 0.49 \\
\hline D & 2.33 & 2.16 & 2.06 & 0.49 \\
\hline E & 1.20 & 0.94 & 1.12 & 0.16 \\
\hline
\end{tabular}

Source: Authors' calculation according to data from financial statements, Serbian Business Registers Agency (SBRA), http://www.apr.gov.rs

On the graphical presentation of these indicators it is distinctly that none of the companies do not have financial stability. In the gray zone we notice a company A, whose value Z'-score has no significant changes. On the other hand, company $\mathrm{D}$ has a rapidly deteriorating in financial operations in 2013, and moves from the zone of indeterminacy in the zone of high probability of bankruptcy. The reason for this lies in the reduction of EBITDA, operating income. Z'-score values of other companies are positioned below the lower limit, the value of 1.23 . At the same time, business activity is in the final year of research significantly decreases, and for these companies there is a risk of the bankruptcy.

Graph 1. Dynamics of Altman's Z-score for companies in the sample

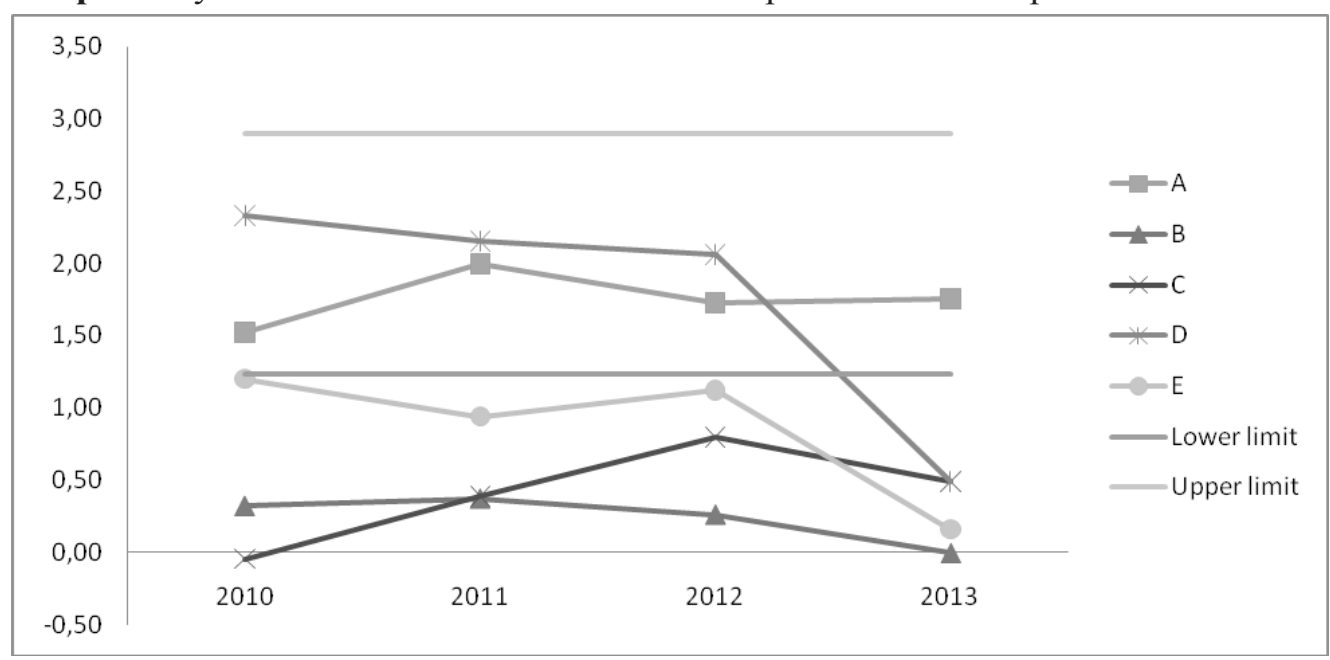

Source: Authors' calculation according to data from financial statements, Serbian Business Registers Agency (SBRA), http://www.apr.gov.rs

Values of Kralicek's functions discrimination give us a new evaluation of the financial situation. Based on the classification that we have mentioned in the methodology, the table of financial stability is as follows. 
Table 4. Calculation of Kralicek's DF indicator for companies in the sample

\begin{tabular}{|l|l|l|l|l|}
\hline \multirow{2}{*}{ Company } & \multicolumn{4}{l}{ The values of DF-indicator } \\
\cline { 2 - 5 } & $\mathbf{2 0 1 0}$ & $\mathbf{2 0 1 1}$ & $\mathbf{2 0 1 2}$ & $\mathbf{2 0 1 3}$ \\
\hline \multirow{3}{*}{ A } & 2.94 & 3.99 & 3.23 & 3.18 \\
\cline { 2 - 5 } & very good & excellent & excellent & excellent \\
\hline \multirow{3}{*}{ B } & 1.17 & 1.12 & 0.82 & 0.35 \\
\cline { 2 - 5 } & average & average & bad & bad \\
\hline \multirow{2}{*}{ C } & -0.08 & 0.06 & 0.42 & -0.1 \\
\cline { 2 - 5 } & moderate insolvency & beginning of insolvency & bad & moderate insolvency \\
\hline \multirow{2}{*}{ D } & 3.17 & 3.07 & 2.84 & 0.86 \\
\cline { 2 - 5 } & excellent & excellent & very good & bad \\
\hline \multirow{2}{*}{ E } & 1.87 & 1.46 & 1.7 & -1.21 \\
\cline { 2 - 5 } & good & average & good & the striking insolvency \\
\hline
\end{tabular}

Source: Authors' calculation according to data from financial statements, Serbian Business Registers Agency (SBRA), http://www.apr.gov.rs

According to the results, we can conclude that the company A continuously has a good, moreover, strong financial stability, and with the results of Altman's test this company has the potential to transfer to a secure, white zone. On the other hand, company B is gradually losing financial stability. Companies $\mathrm{C}$ and $\mathrm{E}$ show great instability. They have positive developments in 2012, but in 2013 they have a drastic deterioration in the financial situation, moderate and extreme insolvency. Excellent results of company D has a significant decline in 2013, therefore the company exceeds the interval of bad financial stability. In the following graph are given representations of Kralicek's discrimination function for each company individually, as well as their positioning in relation to the limit values. 
Graph 2. Dynamics of Kralicek's DF indicator for companies in the sample

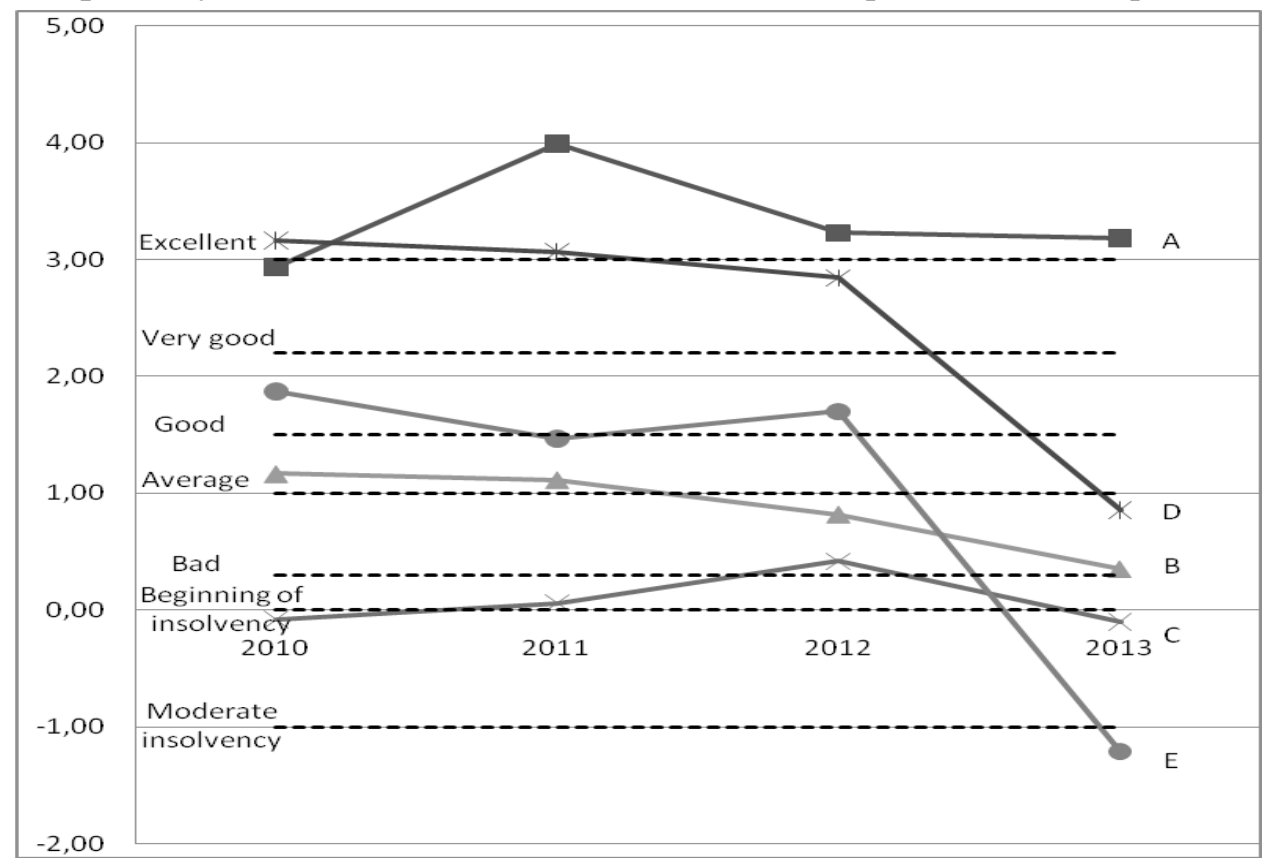

Source: Authors' calculation according to data from financial statements, Serbian Business Registers Agency (SBRA), http://www.apr.gov.rs

Kralicek's Quick test is a test of recent date. Values of four independent indicators, based on the table in the methodology, is assigned with rating from 1 to 5 . A rating of 1 on this scale shows excellent behavior, while the worst score is 5 . Based on the data that we have available for our companies, we calculated the value of the indicators, as well as their grades, where $\mathrm{P}_{\mathrm{i}}$ is the number of points which is at an appropriate value $\mathrm{X}_{\mathrm{i}}$ granted at the table from the methodology, for $\mathrm{i}=1,2,3,4$.

According to Kralicek, assessment of financial stability is an arithmetic mean of score of first two indicators, therefore in the column named $\mathrm{S}_{1}$ we can find estimates of observed companies in the examined period. Column $\mathrm{S}_{2}$ represents the arithmetic mean score of other two indicators and also represents total success and profitability. The arithmetic mean of value $\mathrm{S}_{1}$ and $\mathrm{S}_{2}$, respectively score of all four indicators, representing an overall assessment of the company for the year. 
Table 5. Estimate of Kralicek's Quick test for the companies in the sample

\begin{tabular}{|c|c|c|c|c|c|c|c|c|c|c|c|c|}
\hline \multirow{2}{*}{\multicolumn{2}{|c|}{ Company }} & \multicolumn{4}{|c|}{ Indicators } & \multicolumn{4}{|c|}{ Point } & \multicolumn{3}{|c|}{ Score } \\
\hline & & \multirow{2}{*}{\begin{tabular}{|l|}
$\mathbf{X}_{1}$ \\
0.50
\end{tabular}} & \multirow{2}{*}{\begin{tabular}{|l|}
$\mathbf{X}_{2}$ \\
13.00
\end{tabular}} & \multirow{2}{*}{\begin{tabular}{|l|}
$\mathbf{X}_{3}$ \\
-0.04
\end{tabular}} & \multirow{2}{*}{\begin{tabular}{|l|}
$\mathbf{X}_{4}$ \\
0.03 \\
\end{tabular}} & \multirow{2}{*}{$\begin{array}{l}\mathbf{P}_{1} \\
1\end{array}$} & \multirow{2}{*}{$\begin{array}{l}\mathbf{P}_{2} \\
4\end{array}$} & \multirow{2}{*}{$\begin{array}{l}\mathbf{P}_{3} \\
5\end{array}$} & \multirow{2}{*}{\begin{tabular}{|l}
$\mathbf{P}_{4}$ \\
4
\end{tabular}} & \multirow{2}{*}{\begin{tabular}{|l|}
$\mathbf{S}_{1}$ \\
2.5 \\
\end{tabular}} & \multirow{2}{*}{$\frac{S_{2}}{4.5}$} & \multirow{2}{*}{\begin{tabular}{|l|} 
Total \\
3.5 \\
\end{tabular}} \\
\hline \multirow{4}{*}{ A } & 2010 & & & & & & & & & & & \\
\hline & 2011 & 0.67 & 11.91 & -0.01 & 0.02 & 1 & 3 & 5 & 4 & 2 & 4.5 & 3.25 \\
\hline & 2012 & 0.63 & 22.25 & -0.01 & 0.02 & 1 & 4 & 5 & 4 & 2.5 & 4.5 & 3.5 \\
\hline & 2013 & 0.58 & 25.85 & -0.02 & 0.01 & 1 & 4 & 5 & 4 & 2.5 & 4.5 & 3.5 \\
\hline \multirow{4}{*}{ B } & 2010 & 0.06 & 118.23 & 0.00 & 0.03 & 4 & 5 & 5 & 4 & 4.5 & 4.5 & 4.5 \\
\hline & \begin{tabular}{|l|}
2011 \\
\end{tabular} & 0.06 & 111.86 & 0.00 & 0.05 & 4 & 5 & 4 & 4 & 4.5 & 4 & 4.25 \\
\hline & 2012 & 0.08 & 183.29 & -0.01 & 0.04 & 4 & 5 & 5 & 4 & 4.5 & 4.5 & 4.5 \\
\hline & 2013 & 0.24 & 176.65 & -0.03 & 0.12 & 2 & 5 & 5 & 2 & 3.5 & 3.5 & 3.5 \\
\hline \multirow{4}{*}{$\mathrm{C}$} & 2010 & 0.55 & 43.67 & -0.04 & 0.42 & 1 & 5 & 5 & 1 & 3 & 3 & 3 \\
\hline & 2011 & 0.59 & 50.29 & -0.03 & 0.31 & 1 & 5 & 5 & 1 & 3 & 3 & 3 \\
\hline & 2012 & 0.60 & 80.54 & -0.01 & 0.18 & 1 & 5 & 5 & 1 & 3 & 3 & 3 \\
\hline & 2013 & 0.61 & 89.98 & \begin{tabular}{|l|}
-0.03 \\
\end{tabular} & 0.31 & 1 & 5 & 5 & 1 & 3 & 3 & 3 \\
\hline \multirow{4}{*}{ D } & 2010 & 0.41 & 10.32 & 0.12 & 0.05 & 1 & 3 & 1 & 4 & 2 & 2.5 & 2.25 \\
\hline & 2011 & 0.42 & 17.57 & 0.06 & 0.03 & 1 & 4 & 3 & 4 & 2.5 & 3.5 & 3 \\
\hline & 2012 & 0.38 & 21.46 & 0.04 & 0.02 & 1 & 4 & 4 & 4 & 2.5 & 4 & 3.25 \\
\hline & 2013 & 0.26 & 23.90 & -0.07 & 0.20 & 2 & 4 & 5 & 1 & 3 & 3 & 3 \\
\hline \multirow{4}{*}{ E } & 2010 & 0.33 & 76.51 & 0.02 & 0.02 & 1 & 5 & 4 & 4 & 3 & 4 & 3.5 \\
\hline & \begin{tabular}{|l|}
2011 \\
\end{tabular} & 0.30 & 77.22 & 0.00 & 0.03 & 2 & 5 & 5 & 4 & 3.5 & 4.5 & 4 \\
\hline & 2012 & 0.24 & 83.69 & 0.04 & 0.02 & 2 & 5 & 4 & 4 & 3.5 & 4 & 3.75 \\
\hline & 2013 & 0.12 & 87.37 & -0.12 & 0.36 & 3 & 5 & 5 & 1 & 4 & 3 & 3.5 \\
\hline
\end{tabular}

Source: Authors' calculation according to data from financial statements, Serbian Business Registers Agency (SBRA), http://www.apr.gov.rs

Table 5 indicate that company A has a very good financial stability. Although the Altman's Z-score showed that company A is in the gray zone, Kralicek's DF indicator represents that the company is financially stable, but that there are problems with cost-effectiveness.

Company B has the worst overall ratings of all surveyed companies. In this company, we can notice that positive changes took place in 2013, when significantly increased the share of loans in total liabilities to $24 \%$, in contrast to 2012 when the share was equal to $8 \%$. Due to the sharp decline in operating income, an indicator $\mathrm{X}_{4}$ is increased. Good reviews of these two indicators have contributed to improve the overall assessment of the company.

Company $\mathrm{C}$ has shown the same behavior in terms of all four factors for all four years. Indicators $\mathrm{X}_{1}$ and $\mathrm{X}_{4}$ are with excellent marks which indicate a high coefficient of own funding and a large proportion of cash flow in the business income. Value of indicators $\mathrm{X}_{2}$ is growing through the years, therefore it indicates a long time of pay off debt. Negative values of indicators $\mathrm{X}_{3}$ point to a negative percentage of profitability, consequently it is a 
major reason for the poor financial position of the company.

For company D with this test we confirm once again that in 2013 has deteriorated business in terms of profitability and in terms of their own funding, and we can conclude that the company D estimates continuously declining, and that the situation in the company D through years is getting worse. The similar situation is in the company E.

It is interesting to note that the time pay off debt (column $\mathrm{P}_{2}$ ) for all companies is more than 12 years, which indicates the high indebtedness of agricultural companies in Serbia. Also, from 2011 onwards the percentage of profitability of the total capital is less than $8 \%$, moreover, in all companies in 2013 was negative. Companies B, D and E in the last year of the research show a significant improvement in the share of cash flow in the business income. This data indicates increasing business activities of the company, due to the inflow from operations, and greater financial stability. Results indicate that the cash flow is used to reduce short-term and long-term obligations, causing a gradual recovery of companies. Overall assessment of financial stability for the observed companies are relatively good, except for the company B, which has a poor financial situation and aims of insolvency.

For company A we notice increase of capital in relation to the liabilities. The reason for this is the increase in the revaluation reserves in liabilities and property in the assets of the observed companies. Therefore, we had an unrealistic view of the business and the value of assets in its possession. As a result of this there is a larger property taxes, resulting in a higher outflow of funds, a decline in the value of net profit margin and EBITDA.

Company $\mathrm{C}$ shows the trend of the impossibility of repayment obligations from its own resources as well as increasing the share of capital in total liabilities in revaluation reserves. Thereby, again we have unrealistic view of the assets of company, property in the assets and capital under liabilities. Therefore, cash flows show the realistic situation of the company. For company $\mathrm{C}$ is observed growth in net profit in total revenue on the basis of unrealistic basis, due to unjustified revenues as a consequence of not writing off bad debts.

Company A has a characteristic that its activity falls within the low cumulative branch. During these years we can see an increase in operating income and EBITDA as well. Besides production, company A has begun to deal with trade, and during these years secondary activity is expanding. The reason for that is the turnover cycle of cash, as well as faster time to collect receivables from the customers. Furthermore, the company used shortterm funding sources in the financial market, which has further rise in price in production.

The capital increase for all surveyed companies has a common feature, which refers to the increase in the revaluation reserves, i.e. capital increase is not the result of an increase in profit or increase of the capital. The increase in revaluation reserves has no impact on cash flows, while increasing the capital has, since it represents the introduction of money. In this way we get a blurred image of the operations in all of the analyzed companies and we have no real relationship between owned and borrowed capital. If we exclude increase of the revaluation reserve, we would have seen that the ratio of owned and borrowed capital is the same as in the initial reporting year, which points to the unfavorable capital structure. 
For company B we noticed a big decrease in operating income as a result of the economic crisis due to lack of funds in the market, as well as reduced demand for their products, and the weak purchasing power. Company B had increased participation in the capital, which was created by investing in other legal entities. The largest percentage share of fixed assets included stakes in subsidiaries, which makes it sensitive and dependent on business related legal entities.

The loss was a result of the decrease in operating income in the market and the fact that like other companies observed in this study did not perform the proposed measures to reconstruct the number of employees in the company, which would significantly impact on cost reduction. The fall in the cost of salaries is not accompanied by the decrease of operating income.

The lack of own capital, as well as high financial expenses resulted in a loss above the capital.

\section{Concluding remarks}

Selected companies from the agricultural sector have certain characteristics that they share. Their financial reports indicate an increase in current assets, which is caused by unrealistic and uncollectible receivables, which are not written off and thus influenced the unrealistic picture of the company. Billing cycle for this company's range from 1 up to 4 years.

Companies have not their own capital, and consequently the property belongs to creditors. We imply high revaluation reserves, indicating that the company's assets is overvalued and that there was no assessed at fair value on the market conditions.

Cost of salaries are up to three times higher than operating income, because they do not approach the proposed measures to reconstruct the number of employees in the company, which would reduce costs.

High short-term liabilities of companies as well as unfavorable structure of short-term compared to the long-term liabilities, indicating that companies are mainly financed from costly short-term sources, i.e. production is financed by short-term assets (factoring, discounting bills of exchange) to further increase the cost of production process which results in an increase in financial expenses, which ultimately lead the company to a loss.

According to the Altman's Z-score model, in the case of surveyed companies, it is noted that none of the companies does not have a stable financial operations, except company A which is located in the gray zone of operations. The reason for these operations is a decrease in operating income and high financial expenses, the economic crisis, as well as the inability to collect receivables.

Using Kralicek model and observing the values of DF indicators of sample companies, we conclude that company A has a good financial stability, which with the observed results obtained with Altman's model, indicates that the company is heading towards recovery. The values of other companies point to the great instability in business and decline in value 
in 2012, which are included in moderate or extreme insolvency. The results of these two models showed a very low probability that the observed companies in the next period would get out of financial and business instability. The values clearly indicate the possibility of a bankruptcy or entering the process of pre-pack reorganization plan.

Kralicek's Quick test indicates the indebtedness of agricultural companies in Serbia, as well as the low rate of profitability. Companies that have switched to secondary activity of business recorded growth in operating income due to the fact that the period of collection receivables is shorter. The mismatch of short-term and long-term liabilities and financing companies from costly short-term sources of funding have affected the increase in financial expenses, which in the end lead to the loss of the company and entering the zone of insolvency, which in the future lead to bankruptcy as the only certain solution.

Based on this research, the authors conclude that each of the applied tests gave different answers, as well as the conclusions about company business viewed from different angles. Therefore, the authors recommend that in analyzing the probability of bankruptcy always take into account indicators of different tests.

\section{References}

1. Agarwal, V., Taffler, R. (2007): Twenty-five years of the Taffler z-score model: does it really have predictive ability? Accounting and Business Research, Vol. 37, No. 4, pp. 285-300.

2. Alihodžić, A. (2013): Testing the Kralicek DF indicator application on the Belgrade Stock Exchange. Banking, No. 3, pp. 70-95.

3. Altman, E. (1968): Financial Ratios, Discriminant Analysis and the Prediction of Corporate Bankruptcy. The Journal of Finance, Vol. XXIII, No. 4, pp. 589-609.

4. Beaver, W. H. (1966): Financial Ratios as Predictors of Failure. Empirical Research in Accounting, selected studies (in supplement to the Journal of Accounting Research, January, 1967), pp. 71-111.

5. Deakin, E. B. (1972): A discriminant analysis of predictors of business failure. Journal of Accounting Research (spring), pp. 167-179.

6. Didenko, K., Meziels, J., Vornova, I. (2012): Assessment of Enterprises Insolvency: Challenges and Opportunities. Economics and Management, Vol. 17, No. 1, pp. 69-76.

7. Jakovčević, K., Andrašević, J. (2011): Indikatori poteškoća u funkcionisanju industrijskog preduzeća. Industrija, No. 3, pp. 175-192.

8. Jakšić, D., Vuković, B., Mijić, K. (2011): Analiza finansijskog položaja poljoprivrednih preduzeća u Republici Srbiji. Ekonomika poljoprivrede, Vol. 58, No. 1, pp. 81-90.

9. Machek, O. (2014): Long-Term Predictive Ability of Bankruptcy Models in the Czech Republic: Evidence from 2007-2012. Central European Business Review, Vol. 3, No. 2, pp. 14-17. 
10.Maletić, R., Ćeranić, S., Popović, B. (2011): Mala i srednja preduzeća kao činioci smanjenja siromaštva u ruralnim zajednicama Srbije. Ekonomika poljoprivrede, Vol. 58, No. 1, pp. 121-131.

11. Ministry of Agriculture, Forestry and Water Management of the Republic of Serbia (2014): Strategija poljoprivrede i ruralnog razvoja Republike Srbije za period 20142024. godine, Official Gazette of the Republic of Serbia, No. 85/2014, Belgrade, available at http://uap.gov.rs/wp-content/themes/uap/STRATEGIJA\%202014-2020\%20. pdf

12.Muminović, S., Pavlović, V., Cvijanović, J. M. (2011): Predictive ability of various bankruptcy prediction z-score models for Serbian publicly listed companies. Industrija, Vol. 39, No. 3, pp. 1-12.

13.Muminović, S., Pavlović, V., Cvijanović, J. M. (2012): The impact of investments and changes in the production regime on the results of creditworthiness assessment and bankruptcy prediction models: Case study: Company Bulgari Filati d.o.o. Industrija, Vol. 40, No. 2, pp. 3-18.

14.Ohlson, J. (1980): Financial Ratios and the Probabilistic Prediction of Bankruptcy, Journal of Accounting Research, Vol. 18, No. 1. pp. 109-131.

15.Pavlović, V., Muminović, S., Cvijanović, J. M. (2011): Adequacy of Taffler's model for bankruptcy prediction of Serbian companies. Industrija, Vol. 39, No. 4, pp. 5770.

16.Polo, A., Caca, E. (2014): Kralicek Quick Test - an Analysis Tool for Economic Units Determination in Liability Difficulty. Europena Scientific Journal, Vol. 10, No. 19, pp. 142-152.

17.Smaranda, C. (2014): Scoring Functions and Bankruptcy Prediction Models - Case Study for Romanian Companies. Procedia Economics and Finance Vol. 10, pp. 217 $-226$

18.Stanišić, N., Mizdraković, V., Knežević, G. (2013): Corporate Bankruptcy Prediction in the Republic of Serbia. Industrija, Vol. 41, No. 4, pp. 145-159.

19. Vapa Tankosić, J., Stojsavljević, M. (2012): New perspectives for economic growth: Agribusiness as Serbia's way out of financial crisis, in: European Integration Process in Western Balkan Countries, Teixeira, P., Portugal Duarte, A., Redžepagić, S., Erić, D., Andrejević, S. (Eds.), Faculty of Economics of the University of Coimbra, Coimbra, Portugal, pp. 726-740.

20.Zenzerovic, R., Perusko, T. (2006): Kratki osvrt na modele za predviđanje stečaja? Ekonomska istraživanja, Vol. 19, No. 2, pp. 132-151. 


\title{
MODELI PREDVIĐANJA STEČAJNOG POSTUPKA POLJOPRIVREDNIH PREDUZEĆA U REPUBLICI SRBIJI ${ }^{5}$
}

\author{
Danica Rajin ${ }^{6}$, Danijela Milenković ${ }^{7}$, Tijana Radojevićc ${ }^{8}$
}

\begin{abstract}
Rezime
Cilj ovog rada je prikazivanje različitih modela za predviđanje mogućnosti otvaranja stečajnog postupka u kompanijama u Srbiji, kao i istraživanje koji modeli su najpogodniji za kompanije iz sektora poljoprivrede. U radu su korišćena i prikazana tri modela: Altmanov Z-score model, Kralicekov DF model i Quick test. Ovom tematikom se bavilo dosta autora, međutim, većina njih je razvijala modele na razvijenim tržištima, koja se razlikuju od tržišta Srbije. Težnja ka unapređenju analize i predviđanja stečaja dovela je do upoređivanja referentnih vrednosti, da bi se na kraju došlo do konkretnih modela za procenu poteškoća u funkcionisanju preduzeća. S tim u vezi na uzorku od pet preduzeća koja posluju na teritoriji Republike Srbije, primenili smo tri modela koji koriste standardne finansijske pokazatelje za prikazivanje finansijskog stanja i stabilnosti preduzeća. Rezultati ukazuju da Kralicekov DF model ukazuje na bolje finansijsko stanje preduzeća nego što je ono prikazano Altmanovim Z-score modelom, upravo zbog karakteristika tržišta na kome je model formiran.
\end{abstract}

Ključne reči: Altmanov Z-score, DF model, Quick test, modeli predviđanja stečaja

5 Ovaj rad je deo projekta „Unapređenje konkurentnosti Srbije u procesu pristupanja Srbije Evropskoj uniji““(47028) koji finansira Ministarstvo za nauku i tehnološki razvoj Republike Srbije

6 Saradnik u nastavi, dr Danica Rajin, Univerzitet Singidunum, Fakultet za ekonomiju, finansije i administraciju FEFA, Bulevar Zorana Đinđića br. 44, 11000 Beograd, Srbija, Telefon: +381 113122 440, E-mail: drajin@fefa.edu.rs

7 Asistent, mr Danijela Milenković, Asistent, Univerzitet Singidunum, Fakultet za ekonomiju, finansije i administraciju FEFA, Bulevar Zorana Đinđića br. 44, 11000 Beograd, Srbija, Telefon: +381 113122 440, E-mail: dmilenkovic@,fefa.edu.rs

8 Vanredni profesor, dr Tijana Radojević, Univerzitet Singidunum, Poslovni fakultet u Beogradu, Ulica Danijelova br. 32, 11000 Beograd, Srbija, Telefon: +381 113093 220, E-mail: tradojevic@singidunum.ac.rs

EP 2016 (63) 1 (89-105) 